\title{
Hypoglycemic Activity of Tilia americana, Borago officinalis, Chenopodium nuttalliae, and Piper sanctum on Wistar Rats
}

\author{
Martha P. Rodríguez-Magaña, ${ }^{1}$ Paula Cordero-Pérez ${ }^{(D)},{ }^{2}$ Catalina Rivas-Morales $(\mathbb{D}){ }^{1}$ \\ María A. Oranday-Cárdenas $\mathbb{D}^{1},{ }^{1}$ Diana P. Moreno-Peña ${ }^{(D)}{ }^{2}$ David G. García-Hernández, ${ }^{1}$ \\ and Catalina Leos-Rivas $\mathbb{D i D}^{1}$ \\ ${ }^{1}$ Facultad de Ciencias Biológicas, Departamento de Química, Universidad Autónoma de Nuevo León, Mexico \\ ${ }^{2}$ Facultad de Medicina, Departamento de Medicina Interna, Unidad de Hígado, Universidad Autónoma de Nuevo León, Mexico \\ Correspondence should be addressed to Catalina Leos-Rivas; catalinaleosrivas@yahoo.com
}

Received 2 November 2018; Revised 11 March 2019; Accepted 24 March 2019; Published 16 April 2019

Academic Editor: Rosa Fernandes

Copyright (c) 2019 Martha P. Rodríguez-Magaña et al. This is an open access article distributed under the Creative Commons Attribution License, which permits unrestricted use, distribution, and reproduction in any medium, provided the original work is properly cited.

\begin{abstract}
Diabetes mellitus (DM) is considered the epidemic of the 21st century. Traditional medicine uses plants to treat DM; many of these have hypoglycemic effects in both animal models and diabetic patients. Our objective was to evaluate the hypoglycemic activity of Tilia americana, Borago officinalis, Chenopodium nuttalliae, and Piper sanctum on diabetic rats. The methanolic extracts of the plants under study were obtained by Soxhlet extraction. Toxicity was evaluated on Artemia salina; the antioxidant potential was evaluated using the DPPH technique. Hypoglycemic capacity at doses of 250 and $500 \mathrm{mg} / \mathrm{kg}$ was tested on Wistar rats with diabetes induced by alloxan $(120 \mathrm{mg} / \mathrm{kg})$. The toxicity on A. salina was null for the extracts of B. officinalis and P. sanctum, moderate for T. americana, and highly toxic for $C$. nuttalliae. The relevant extract of T. americana var. mexicana showed antioxidant activity. Three plants of the studied plants showed hypoglycemic activity: Tilia Americana $(p=0.0142)$, Borago officinalis $(p=0.0112)$, and Piper sanctum $(p=0.0078)$; . sanctum was the one that showed the greatest reduction in glucose levels at a lower dose.
\end{abstract}

\section{Introduction}

Diabetes mellitus (DM) is a metabolic disease characterized by an elevated level of blood glucose that is associated in the long term with the dysfunction of different organs. Left untreated, it can cause blindness, renal insufficiency, myocardial infarction, cerebrovascular accidents, or amputation of the lower limbs [1].

DM is considered the epidemic of the 21 st century, and its prevalence has increased in low- and middle-income countries. It is estimated that DM caused 1.6 million deaths in 2015 (WHO 2017) and is projected to be the seventh cause of mortality by $2030[2,3]$.

Most diabetic patients are included into two groups, type I (total deficiency of insulin secretion) and type II (insulin resistance). Treatment of type I diabetes is based on diet and the administration of insulin. Treatment of type II diabetes starts with diet and physical exercise; if the response is not adequate, then hypoglycemic drugs are administered orally (sulfonylureas and metformin).

Many plants used in traditional medicine (Momordica charantia, Terminalia paniculata Bar, Scrophularia ningpoensis, and Anemarrhena asphodeloides, among others) are used to treat patients with DM in various parts of the world, mainly in developing countries. The hypoglycemic effect of a large number of these plants or their preparations has been confirmed in animal models $[4,5]$, as well as in diabetic patients [6-8]. Among the active compounds with hypoglycemic effect that have been isolated are alkaloids, terpenoids [9], flavonoids [10], and saponins [11]. 
In this study, four plants of different families used in traditional medicine were chosen to evaluate hypoglycemic activity.

The leaves of Piper sanctum (Piperaceae) are used as tea to treat stomach cramps, coughs, bronchitis, tuberculosis, asthma, and colds and as a poultice in skin irritations and arthritis. The presence of alkaloids and lactones with antibacterial activity is reported for this plant [12]. Another species, $P$. betle, shows the presence of terpenes and phenols with relevant antidiabetic activity [13].

Tilia americana var. mexicana (Malvaceae) has anxiolytic and sedative properties as well as antioxidant activity and is used as a soother or relaxant [14] for the neural damage induced by intestinal ischemia [15]. T. cordata is used in traditional medicine for the treatment of diabetes, and other plants of the same family have hypoglycemic activity [16].

Oil of Borago officinalis (Boraginaceae) is marketed as a nutritional supplement for being a source of oleic and linoleic acids. Borage seed oil is used in the treatment of various diseases such as multiple sclerosis, diabetes, heart disease, arthritis and eczema [17], and gastrointestinal and cardiovascular disorders as well as for atopic dermatitis [18]. This plant has anti-inflammatory and antioxidant properties due to the flavonoids and sterols that have been isolated from it $[19,20]$. Another plant from the same family, Heliotropium strigosum, reduced the blood glucose level of diabetic mice induced by alloxan, and the presence of alkaloids, tannins, proteins, steroids, and flavonoids is reported [21].

Chenopodium nuttalliae is used to combat mental and physical fatigue. To date, there is no activity described for C. nuttalliae (Chenopodiaceae); however, several plants of this family show hypoglycemic activity [22]. Other plants of the same genus, such as C. ambrosioides, show antifungal, antiaflatoxigenic, and antioxidant activities [23].

Due to the aforementioned background, our objective was to evaluate the hypoglycemic activity of T. americana, B. officinalis, C. nuttalliae, and P. sanctum on diabetic rats.

\section{Materials and Methods}

2.1. Vegetal Material. B. officinalis was collected from Saltillo, Coahuila $\left(25.4383^{\circ} \mathrm{N}, 100.9737^{\circ} \mathrm{W}\right.$ ) (record number 27344 ); C. nuttalliae from Monterrey, Nuevo Leon $\left(25.6866^{\circ} \mathrm{N}\right.$, $100.3161^{\circ} \mathrm{W}$ ) (record number 27799); T. americana var. mexicana from Morelia, Michoacan $\left(19.7060^{\circ} \mathrm{N}, 101.1950^{\circ}\right.$ W) (record number 27797); and P. sanctum from Mexico City $\left(19.4326^{\circ} \mathrm{N}, 99.1332^{\circ} \mathrm{W}\right)$ (record number 27798). The plants were identified in the Department of Botany of the College of Biological Sciences, Universidad Autónoma de Nuevo León (UANL), Mexico.

The material was dried in the shade at room temperature, and the leaves were separated and crushed in a manual mill. For each plant, $200 \mathrm{~g}$ were taken and deposited in a Soxhlet extractor with methanol as solvent. The samples were left in reflux for $40 \mathrm{~h}$ to later concentrate the extract with a Büchi-type rotary evaporator at a temperature lower than $60^{\circ} \mathrm{C}$. The concentrate was dried at ambient temperature and was stored in amber-colored vials at $4^{\circ} \mathrm{C}$ until use. For administration in the animal model, the dry extracts were solubilized in physiological solution using a sonicator.

2.2. Phytochemical Profile of Extracts. The methanolic extracts were subjected to a phytochemical profile by means of qualitative colored tests for the identification of flavonoids (Shinoda test), coumarins ( $\mathrm{NaOH}$ test), alkaloids (Dragendorff test), sugars (Antrona test), sesquiterpenectones (Baljet test), tannins ( $\mathrm{FeCl}_{3}$ test), sterols, and terpenoids (Liebermann-Burchard test) [24].

2.3. Lethality Test on Artemia salina. Artificial seawater (Instant Ocean) was prepared, adjusting the $\mathrm{pH}$ to 7.8. The aquarium was ventilated with a pump for $24 \mathrm{~h}$. A. salina nauplii were hatched in a rectangular glass container $(17 \mathrm{~cm} \times 14 \mathrm{~cm} \times 7 \mathrm{~cm})$ with a dark chamber for cyst incubation and illuminated to obtain the nauplii by phototropism. They were incubated $48 \mathrm{~h}$ at room temperature $\left(23-25^{\circ} \mathrm{C}\right)$ with constant aeration, after which the assay was carried out in 96-well microplates (Costar, Corning, NY, USA). Ten nauplii were deposited in wells containing a final volume of $200 \mu \mathrm{L}$ and concentrations of $100-1000 \mu \mathrm{g} / \mathrm{mL}$ of each extract of the plants under study and incubated for $24 \mathrm{~h}$, and dead nauplii were counted using a stereoscope [25].

2.4. Experimental Animal Model. This study was carried out under the approval of the ethics committee of the College of Medicine of the UANL (registration no. HI11-002) following the provisions of the Official Mexican Standard NOM062-ZOO-1999 technical specifications for the production, care, and use of laboratory animals. The animals were kept under appropriate conditions of light, temperature, and humidity, and they were given standard diet for rodents and water ad libitum.

2.5. Diabetes Animal Model. Diabetes was induced in male Wistar rats (180-240 g) by the administration of a single dose of alloxan, intraperitoneally (120 mg/kg of weight). After injection, they were provided with a $5 \%$ dextrose solution in the drinking fountains to overcome the hypoglycemic phase. After $48 \mathrm{~h}$, blood samples were collected through a puncture at the tip of the tail and the glucose levels were determined by test strips using a glucometer (ACCU CHECK Roche); if the level was greater than $250 \mathrm{mg} / \mathrm{dL}$, the rat was selected for the study [26].

2.6. Experimental Design. We used 72 diabetic rats, which were distributed randomly into 8 groups with 9 rats each. The basal glucose was measured in the test animals, and subsequently, a methanolic extract of each of the plants at a dose of 250 and $500 \mathrm{mg} / \mathrm{kg}$ of weight or physiological solution (control group) was administered by means of an intragastric probe. After $4 \mathrm{~h}$, a second glucose measurement was made. These doses were determined based on a review of the antidiabetic activity of plants made by our group, in which reported doses oscillated between 200 and $500 \mathrm{mg} / \mathrm{kg}$ [27].

2.7. Antioxidant Activity. To evaluate the antioxidant activity, the method of reduction of the 1,1-diphenyl-2-picrylhydrazyl (DPPH) radical was used [28]. The methanolic 
extracts were evaluated at concentrations of 3.125 to $1000 \mathrm{ppm}$. The DPPH (Sigma-Aldrich) was prepared to $125 \mu \mathrm{M}$ in methanol, $100 \mu \mathrm{L}$ of each sample was taken, and $100 \mu \mathrm{L}$ of DPPH was added; the samples were allowed to stand for $30 \mathrm{~min}$ protected from light. The absorbance at $517 \mathrm{~nm}$ was measured using a spectrophotometer (Jenway $320 \mathrm{~d})$. As a positive control, a solution of tocopherol (Sigma-Aldrich) was used and as negative control EtOH; the reduction percentage was calculated using

$$
\% \text { Reduction }=\frac{\text { Absorbancy negative control }- \text { Absorbancy sample }}{\text { Absorbancy negative control }} \times 100 \text {. }
$$

2.8. Statistics. The mean lethal dose $\left(\mathrm{LD}_{50}\right)$ and the mean lethal concentration $\left(\mathrm{LC}_{50}\right)$ were determined by means of a probit regression with the software SPSS version 17. In the animal model, a nonparametric " $t$ " test was performed to determine the significant difference in the reduction of glucose for each group using the GraphPad 7.0 program; a value of $p<0.05$ was considered significant.

\section{Results and Discussion}

3.1. Results. The phytochemical profile of the four plant extracts showed flavonoids, sugars, sterols, and terpenoids. B. officinalis also showed quinones, sesquiterpenlactone, alkaloids, and tannins, while in P. sanctum, sesquiterpenlactone, coumarins, alkaloids, and tannins. The extracts of $T$. americana showed coumarins and tannins, and those of $C$. nuttalliae also showed coumarins.

3.1.1. Toxicity Test on Artemia salina. We evaluated the toxic activity of the methanolic extracts of T. americana var. mexicana, B. officinalis, C. nuttalliae, and P. sanctum against the nauplii of $A$. salina. The extracts with lower toxicity were $B$. officinalis and P. sanctum (Table 1). The toxic activity was calculated according to the classification reported by Syahmi et al. [29] based on their $\mathrm{LC}_{50}$ value $(0-100 \mu \mathrm{g} / \mathrm{mL}$, high; $100-$ $500 \mu \mathrm{g} / \mathrm{mL}$, moderate; $500-1000 \mu \mathrm{g} / \mathrm{mL}$, low; and a value higher than $1000 \mu \mathrm{g} / \mathrm{mL}$, nontoxic).

3.1.2. Hypoglycemic Activity. The group of diabetic rats maintained their elevated glucose levels during the study period (baseline, $380.6 \pm 68.1 \mathrm{mg} / \mathrm{dL} ; 4 \mathrm{~h}, 377.88 \pm 70.9 \mathrm{mg} / \mathrm{dL}$; $p>0.05)$; the negative control group maintained its normal glucose levels (baseline, $116.0 \pm 15.4 \mathrm{mg} / \mathrm{dL} ; 4 \mathrm{~h}$, $121.3 \pm 12.5 \mathrm{mg} / \mathrm{dL} ; p>0.05)$. When evaluating the two doses (250 and $500 \mathrm{mg} / \mathrm{kg}$ of weight) of the methanolic extracts of each plant, only B. officinalis and T. americana showed relevant hypoglycemic activity $4 \mathrm{~h}$ posttreatment at a dose of $500 \mathrm{mg} / \mathrm{kg}(p=0.0112)$, whereas $P$. sanctum higher showed antihypoglycemic effect at a dose of $250 \mathrm{mg} / \mathrm{kg}$ $(p=0.0078)$ of weight (Figure 1$)$.

3.1.3. Antioxidant Activity. When evaluating the antioxidant activity of the methanolic extracts (DPPH), it was observed that the extract of $T$. americana showed a higher activity compared with the other extracts under study with an $\mathrm{EC}_{50}$ of $8.84 \pm 1.05 \mathrm{mg} / \mathrm{mL}$ (Table 2 ).
TABLE 1: Toxic activity on A. salina based on $\mathrm{LC}_{50}$ of each study extract. Values are expressed as mean \pm SD.

\begin{tabular}{lcc}
\hline Extracts & $\mathrm{LC}_{50}(\mathrm{ppm})$ & Category \\
\hline T. americana & $572.74 \pm 5.72$ & Moderately toxic \\
B. officinalis & $>1000$ & Nontoxic \\
C. nuttalliae & $41.13 \pm 3.12$ & Highly toxic \\
P. sanctum & $>1000$ & Nontoxic \\
\hline
\end{tabular}

3.2. Discussion. The interest in natural alternatives for the treatment of diabetes has led to the evaluation of a large number of plants in the search for bioactive compounds with possible hypoglycemic activity; however, it is important to rule out a toxic effect of plants when evaluating said activity. In the rat model, our study plants showed hypoglycemic activity.

We found that T. americana showed hypoglycemic activity at the dose of $500 \mathrm{mg}$, although it presented moderate toxicity. No previous studies showed such activity for this plant, although this activity is reported in another species of the same genus [15]. In this study, this plant was the one that showed the greatest antioxidant activity, even greater than the control (Table 2). This activity may be related to the presence of flavonoids, previously reported by other authors $[14,30]$. T. americana was moderately toxic on A. salina, which, to our knowledge, has not been previously reported.

Several plants of the family Chenopodiaceae have medicinal effects. For example, Anabasis articulata has antihyperglycemic effects [31]; Salsola kali, S. soda, and S. oppositifolia are inhibitors of alpha amylase [32]; and Atriplex halimus is an antidiabetic and Chenopodium ambrosioides is hypoglycemic [33]. In this study, we found that C. nuttalliae showed low hypoglycemic activity. Chikhi et al. [22] report a significant antioxidant for this plant, whereas we found low antioxidant activity. C. nuttalliae was highly toxic for A. salina, which has not been previously reported; $2,873.23 \mathrm{mg}$ of $100 \cdot \mathrm{g}^{-1}$ dry matter of saponins was found in this plant's sprouts, conferring moderate toxicity [33].

B. officinalis showed hypoglycemic activity, and this is increased with respect to the dose used. It has been described that this plant is rich in gamma-linolenic acid that has been used as a medicine to treat various diseases such as diabetes, local eczema, heart disease, cyclical mastalgia, arthritis, and multiple sclerosis $[34,35]$. In another plant of the $B$. officinalis family, this activity has also been reported [21]. The antioxidant activity found was low, and although the phytochemical profile showed the presence of flavonoids, to which this property is attributed, it also contains other compounds which can interfere in biological activity [19, 20, 36, 37]. It showed no toxicity on $A$. salina, and there are no reports of toxicity in this plant.

The Piper species show different activities; for example, $P$. auritum has terpenes, flavonoids, essential oils, and alkaloids and Piper betle has terpenes and phenols that are related to hypoglycemic [13, 38] and antioxidant activity [39], 

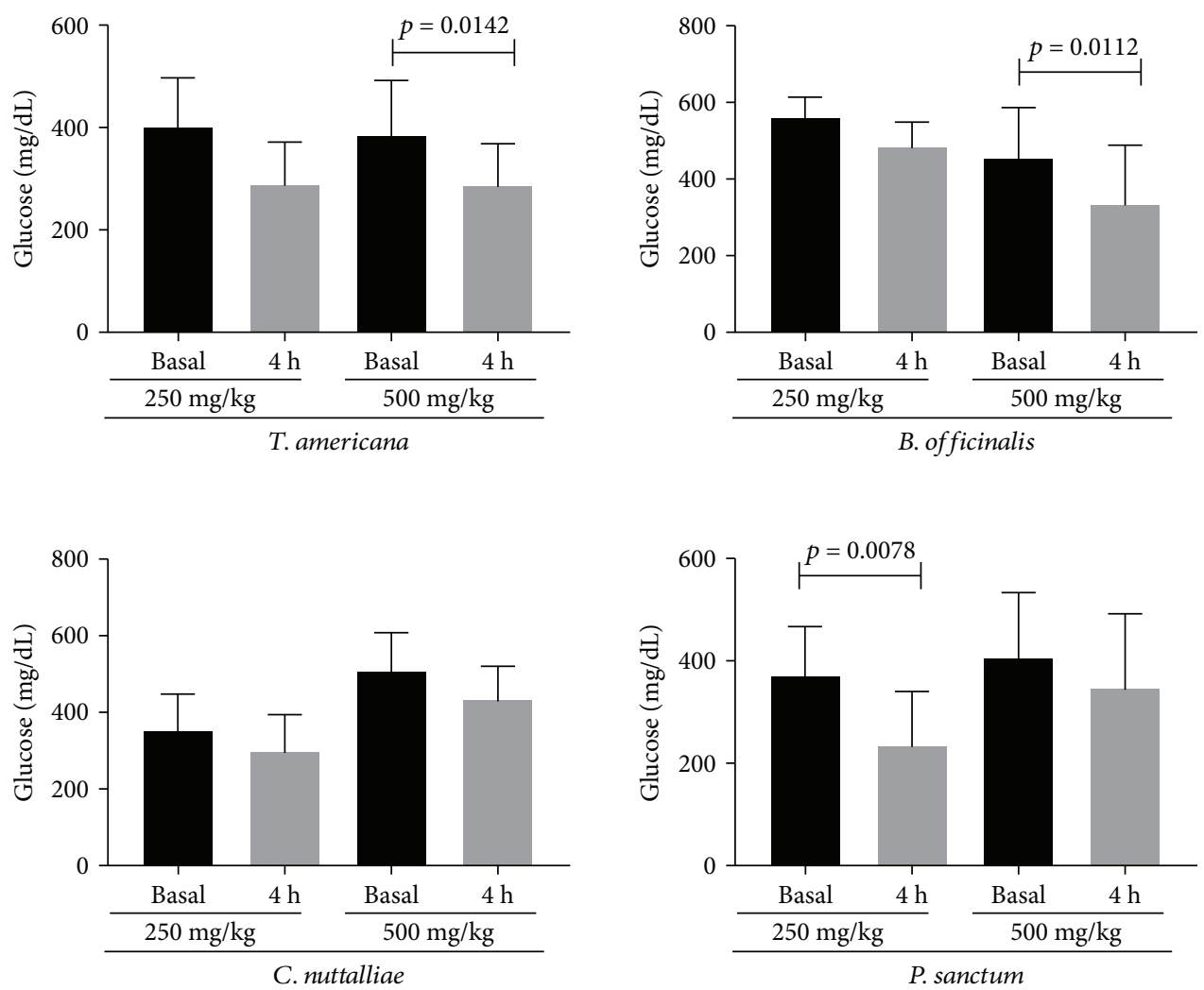

Figure 1: Glucose levels, basal and 4 hours after the administration of the extracts under study at doses of 250 and $500 \mathrm{mg} / \mathrm{kg}$. Values are expressed as mean \pm SD.

TABLE 2: DPPH radical scavenging activities of the extracts. Values are expressed as mean $\pm \mathrm{SD}$.

\begin{tabular}{lc}
\hline Extracts & $\mathrm{EC}_{50}(\mathrm{mg} / \mathrm{mL})$ \\
\hline B. officinalis & $255.74 \pm 5.24$ \\
C. nuttalliae & $382.30 \pm 8.32$ \\
T. Americana var. mexicana & $8.84 \pm 1.05$ \\
P. sanctum & $482.30 \pm 9.38$ \\
Tocopherol (positive control) & $9.34 \pm 2.02$ \\
\hline
\end{tabular}

whereas for P. sanctum, only antibacterial activity related to the presence of alkaloids and lactones has been reported [12]. In this study, we found sterols, flavonoids, coumarins, alkaloids, and tannins, which may be related to biological activity. Of the four plants studied, the extract of $P$. sanctum was the best because it presented a greater hypoglycemic effect at a lower dose $(250 \mathrm{mg} / \mathrm{kg}$ of weight). When the dose was increased, the activity was lower: this may be due to the fact that regardless of the mechanism of the active principle, the effect depends on the concentration. However, the relationship of the effect with the concentration can be complex and is not usually linear [40]. This is the first report of hypoglycemic activity for this species of the Piper genus. It did not show toxicity on A. salina, unlike that reported by Déciga-Campos et al. [41] where it was significant.
The model of alloxan-induced diabetes has been widely used to evaluate the hypoglycemic activity of various plant extracts, in which a hypoglycemic effect has been reported within the first hours (1-8h) after administration [42, 43]. This effect is also reported for drugs such as glibenclamide and tolbutamide, in these same periods postadministration. In the present study, we evaluated the hypoglycemic effect at 4 hours postadministration based on previous studies. This effect, when observed after the $\beta$-cells were destroyed, suggests that the extract could have a stimulating effect on the remaining $\beta$-cells, or we could suppose that the extracts favor the use of glucose at the cellular level with a similar effect. As for insulin, however, studies are needed to elucidate the possible mechanism of action [44-47].

\section{Conclusions}

Three plants evaluated showed hypoglycemic activity, $P$. sanctum being the one that showed the greatest reduction in glucose levels at a lower dose. This activity could be related to the presence of flavonoids and alkaloids that have already been associated with hypoglycemic activity. This plant did not present toxicity for $A$. salina at the doses evaluated, and this is the first time that it is reported to have hypoglycemic activity. The methanolic extract of T. americana var. mexicana presented antioxidant activity and had moderate toxicity. Further research is needed to identify the metabolites responsible for the biological activity of the plants evaluated. 


\section{Data Availability}

The data used to support the findings of this study are included within the article.

\section{Conflicts of Interest}

The authors declare that there is no conflict of interest regarding the publication of this paper.

\section{Acknowledgments}

This project was supported by the Consejo Nacional de Ciencia y Tecnología, CONACYT (53430), and Programa de Apoyo a la Investigación Cinetífica y Tecnológica, PAICyT-UANL (CN589-18). Alejandra E. Arreola Triana provided editorial support for this manuscript.

\section{References}

[1] American Diabetes Association, "Diagnosis and classification of diabetes mellitus," Diabetes Care, vol. 37, Supplement 1, pp. S81-S90, 2014.

[2] C. D. Mathers and D. Loncar, "Projections of global mortality and burden of disease from 2002 to 2030," PLoS Medicine, vol. 3, no. 11, article e442, 2006.

[3] World Health Organization, Global Report on Diabetes, 2017, http://apps.who.int/iris/bitstream/handle/10665/204871/978 9241565257_eng.pdf;jsessionid=27CD6A1F9B93CFF1EFF19 498C6FFEC48? sequence $=1$.

[4] R. Srinivasan, U. M. Dhanalekshmi, T. Gowri, and S. Duarah, "Terminalia paniculata bark extract for antidiabetic activity," International Journal of Pharmaceutical Sciences and Research, vol. 7, no. 3, pp. 1331-1337, 2016.

[5] Y. Lu, J. L. Li, Q. Jiang et al., "Effect of Scrophularia ningpoensis extract on diabetes in rats," Tropical Journal of Pharmaceutical Research, vol. 16, no. 6, pp. 1331-1335, 2017.

[6] I. Ahmed, E. Adeghate, E. Cummings, A. K. Sharma, and J. Singh, "Beneficial effects and mechanism of action of Momordica charantia juice in the treatment of streptozotocin-induced diabetes mellitus in rat," Molecular and Cellular Biochemistry, vol. 261, no. 1, pp. 63-70, 2004.

[7] Z. C. Thent, S. Das, and N. H. Zaidun, "Emerging trends on drug delivery strategy of Momordica charantia against diabetes and its complications," Current Drug Delivery, vol. 15, no. 4, pp. 453-460, 2018.

[8] R. Zhang, L. Yang, J. Ji, B. B. Li, L. Li, and M. Ye, "Physicochemical properties and hypoglycaemic activity of fermented milks prepared with Anemarrhena asphodeloides water extracts," Journal of the Science of Food and Agriculture, vol. 96, no. 2, pp. 492-496, 2016.

[9] J. C. Chukwujekwu, K. R. R. Rengasamy, C. A. de Kock, P. J. Smith, L. P. Slavětínská, and J. van Staden, "Alpha-glucosidase inhibitory and antiplasmodial properties of terpenoids from the leaves of Buddleja saligna Willd," Journal of Enzyme Inhibition and Medicinal Chemistry, vol. 31, no. 1, pp. 63-66, 2016.

[10] S. V. Bhadada and R. K. Goyal, "Effect of flavonoid rich fraction of Tephrosia purpurea (Linn.) Pers. on complications associated with streptozotocin-induced type I diabetes mellitus," Indian Journal of Experimental Biology, vol. 54, no. 7, pp. 457-466, 2016.
[11] N. Lavie, P. Shukia, and A. Panchal, "Role of flavonoids and saponins in the treatment of diabetes mellitus," Journal of Pharmaceutical Science and Bioscientific Research, vol. 6, no. 4, pp. 535-541, 2016.

[12] R. Mata, I. Morales, O. Pérez et al., "Antimycobacterial compounds from Piper sanctum," Journal of Natural Products, vol. 67, no. 12, pp. 1961-1968, 2004.

[13] L. S. R. Arambewela, L. D. A. M. Arawwawala, and W. D. Ratnasooriya, "Antidiabetic activities of aqueous and ethanolic extracts of Piper betle leaves in rats," Journal of Ethnopharmacology, vol. 102, no. 2, pp. 239-245, 2005.

[14] N. Cárdenas-Rodríguez, M. E. González-Trujano, E. AguirreHernández et al., "Anticonvulsant and antioxidant effects of Tilia americana var. mexicana and flavonoids constituents in the pentylenetetrazole-induced seizures," Oxidative Medicine and Cellular Longevity, vol. 2014, Article ID 329172, 10 pages, 2014.

[15] G. E. Angeles-López, M. E. González-Trujano, M. DécigaCampos, and R. Ventura-Martínez, "Neuroprotective evaluation of Tilia americana and Annona diversifolia in the neuronal damage induced by intestinal ischemia," Neurochemical Research, vol. 38, no. 8, pp. 1632-1640, 2013.

[16] S. A. Otoom, S. A. Al-Safi, Z. K. Kerem, and A. Alkofahi, "The use of medicinal herbs by diabetic Jordanian patients," Journal of Herbal Pharmacotherapy, vol. 6, no. 2, pp. 31-41, 2006.

[17] M. Asadi-Samani, M. Bahmani, and M. Rafieian-Kopaei, "The chemical composition, botanical characteristic and biological activities of Borago officinalis: a review," Asian Pacific Journal of Tropical Medicine, vol. 7, pp. S22-S28, 2014.

[18] R. H. Foster, G. Hardy, and R. G. Alany, "Borage oil in the treatment of atopic dermatitis," Nutrition, vol. 26, no. 7-8, pp. 708-718, 2010.

[19] F. Conforti, S. Sosa, M. Marrelli et al., "In vivo antiinflammatory and in vitro antioxidant activities of Mediterranean dietary plants," Journal of Ethnopharmacology, vol. 116, no. 1, pp. 144-151, 2008.

[20] A. H. Gilani, S. Bashir, and A. U. Khan, "Pharmacological basis for the use of Borago officinalis in gastrointestinal, respiratory and cardiovascular disorders," Journal of Ethnopharmacology, vol. 114, no. 3, pp. 393-399, 2007.

[21] H. Aslam, A.-u. Khan, N.-u. Rehman, F. Ali, H. Nadeem, and S. M. Shah, "Anti-hyperglycemic activity of Heliotropium strigosum (Boraginaecae) whole plant extract in alloxan-induced diabetic mice," Tropical Journal of Pharmaceutical Research, vol. 16, no. 10, pp. 2425-2430, 2017.

[22] I. Chikhi, H. Allali, M. el Amine Dib, H. Medjdoub, and B. Tabti, "Antidiabetic activity of aqueous leaf extract of Atriplex halimus L.(Chenopodiaceae) in streptozotocin-induced diabetic rats," Asian Pacific Journal of Tropical Disease, vol. 4, no. 3, pp. 181-184, 2014.

[23] R. Kumar, A. K. Mishra, N. K. Dubey, and Y. B. Tripathi, "Evaluation of Chenopodium ambrosioides oil as a potential source of antifungal, antiaflatoxigenic and antioxidant activity," International Journal of Food Microbiology, vol. 115, no. 2, pp. 159-164, 2007.

[24] M. J. Verde-Star, S. García-González, and C. Rivas-Morales, "Metodología científica para el estudio de plantas medicinales," in Investigación en plantas de importancia médica, C. Rivas-Morales, M. A. Oranday-Cardenas, and M. J. Verde-Star, Eds., pp. 1-40, OmniaScience, Barcelona, España, 1st edition, 2016. 
[25] G. M. Molina-Salinas and S. Said-Fernández, “A modified microplate cytotoxicity assay with brine shrimp larvae (Artemia salina)," Pharmacology, vol. 3, pp. 633-638, 2006.

[26] G. Jelodar, M. Mohsen, and S. Shahram, "Effect of walnut leaf, coriander and pomegranate on blood glucose and histopathology of pancreas of alloxan induced diabetic rats," African Journal of Traditional, Complementary, and Alternative Medicines, vol. 4, no. 3, pp. 299-305, 2008.

[27] D. M. Ortíz-Martínez, P. Cordero-Pérez, and C. Leos-Rivas, "Actividad antidiabética," in Investigación en Plantas de Importancia Médica, C. Rivas-Morales, M. A. Oranday-Cardenas, and M. J. Verde-Star, Eds., pp. 1-40, OmniaScience, Barcelona, España, 1st edition, 2016.

[28] L. E. García-Becerra, C. Leos-Rivas, M. A. Oranday-Cárdenas, and C. Rivas-Morales, "Free radical scavenging and cytotoxic activity of five commercial standardized extracts (red wine, green tea, pine bark, Polygonum and pomegranate)," African Journal of Biotechnology, vol. 11, no. 102, pp. 16725-16730, 2012.

[29] A. R. M. Syahmi, S. Vijayarathna, S. Sasidharan et al., "Acute oral toxicity and brine shrimp lethality of Elaeis guineensisJacq., (oil palm leaf) methanol extract," Molecules, vol. 15, no. 11, pp. 8111-8121, 2010.

[30] E. Aguirre-Hernández, M. E. González-Trujano, A. L. Martínez et al., "HPLC/MS analysis and anxiolytic-like effect of quercetin and kaempferol flavonoids from Tilia americana var. mexicana," Journal of Ethnopharmacology, vol. 127, no. 1, pp. 91-97, 2010.

[31] N. Kambouche, B. Merah, A. Derdour et al., "Hypoglycemic and antihyperglycemic effects of Anabasis articulata (Forssk) Moq (Chenopodiaceae), an Algerian medicinal plant," African Journal of Biotechnology, vol. 8, no. 20, pp. 5589-5594, 2009.

[32] R. Tundis, M. R. Loizzo, G. A. Statti, and F. Menichini, "Inhibitory effects on the digestive enzyme $\alpha$-amylase of three Salsola species (Chenopodiaceae) in vitro," Pharmazie, vol. 62, no. 6, pp. 473-475, 2007.

[33] M. R. Barrón-Yánez, C. Villanueva-Verduzco, M. R. GarcíaMateos, and M. T. Colinas-León, "Nutrient value and saponin content of huauzontle (Chenopodium nuttalliae Saff.), zucchini (Cucurbita pepo L.), canola (Brassica napus L.) and amaranto (Amaranthus leucocarpus S. Watson syn. hypochondriacus L.) sprouts," Revista Chapingo Serie Horticultura, vol. XV, no. 3, pp. 237-243, 2009.

[34] C. K. Chow, Fatty Acids in Foods and Their Health Implications, Marcel Dekker, Inc., New York, NY, USA, 1st edition, 1992.

[35] D. F. Horrobin, "Clinical applications of n-6 essential fatty acids: atopic eczema and inflammation, diabetic neuropathy and retinopathy, breast pain and viral infections," in Essential Fatty Acids and Eicosanoids; Invited Papers from the Third International Congress, A. Sinclair and R. Gibson, Eds., pp. 367-372, American Oil Chemists' Society, Champaign, IL, USA, 1992.

[36] P. G. Peiretti, G. B. Palmegiano, and G. Salamano, "Quality and fatty acid content of borage (Borago officinalis L.) during the growth cycle," Italian Journal of Food Science, vol. 16, no. 2, pp. 177-184, 2004.

[37] N. A. Jaradat, B. Damiri, and M. N. Abualhasan, "Antioxidant evaluation for Urtica urens, Rumex cyprius and Borago officinalis edible wild plants in Palestine," Pakistan Journal of Pharmaceutical Sciences, vol. 29, Supplement 1, pp. 325-330, 2016.
[38] A. Andrade-Cetto and M. Heinrich, "Mexican plants with hypoglycaemic effect used in the treatment of diabetes," Journal of Ethnopharmacology, vol. 99, no. 3, pp. 325-348, 2005.

[39] D. Choudhary and R. K. Kale, "Antioxidant and non-toxic properties of Piper betle leaf extract: in vitro and in vivo studies," Phytotherapy Research, vol. 16, no. 5, pp. 461-466, 2002.

[40] A. Cafiero Moroney, "Relaciones dosis-respuestaRenal CSM Organization, Global Medical Affairs, GPRD, AbbVie, IncAugust 2018, https://www.msdmanuals.com/es-mx/professional/ farmacolog\%C3\%ADa-cl\%C3\%ADnica/farmacodin\%C3\%A1 mica/relaciones-dosis-respuesta.

[41] M. Déciga-Campos, I. Rivero-Cruz, M. Arriaga-Alba et al., "Acute toxicity and mutagenic activity of Mexican plants used in traditional medicine," Journal of Ethnopharmacology, vol. 110, no. 2, pp. 334-342, 2007.

[42] B. C. Castañeda, R. C. de la Mata, R. M. Mejia, L. I. Vasquez, R. F. Alarcón, and E. B. Mendoza, "Estudio fitoquímico y farmacológico de 4 plantas con efecto hipoglicemiante," Horizonte Médico, vol. 8, no. 1, pp. 6-34, 2008.

[43] B. K. Rao, M. M. Kesavulu, and C. Apparao, "Antihyperglycemic activity of Momordica cymbalaria in alloxan diabetic rats," Journal of Ethnopharmacology, vol. 78, no. 1, pp. 67-71, 2001.

[44] F. J. Alarcon-Aguilar, R. Roman-Ramos, J. L. Flores-Saenz, and F. Aguirre-Garcia, "Investigation on the hypoglycaemic effects of extracts of four Mexican medicinal plants in normal and Alloxan-diabetic mice," Phytotherapy Research, vol. 16, no. 4, pp. 383-386, 2002.

[45] O. Herrera Calderón, R. Chinchay Salazar, E. Palomino Ormeño, E. Arango Valencia, and J. Arroyo, "Efecto hipoglucemiante del extracto etanólico de Geranium ruizii Hieron.(pasuchaca) en la hiperglucemia inducida por aloxano en ratas," in Anales de la Facultad de Medicina, vol. 76, no. 2, pp. 117-122, 2015.

[46] S. M. Njogu, W. M. Arika, A. K. Machocho, J. J. N. Ngeranwa, and E. N. M. Njagi, "In vivo hypoglycemic effect of Kigelia africana (Lam): studies with alloxan-induced diabetic mice," Journal of Evidence-Based Integrative Medicine, vol. 23, p. 2515690X1876872, 2018.

[47] H. Van Doan, S. Riyajan, R. Iyara, and N. Chudapongse, "Antidiabetic activity, glucose uptake stimulation and $\alpha$-glucosidase inhibitory effect of Chrysophyllum cainito L. stem bark extract," BMC Complementary and Alternative Medicine, vol. 18, no. 1, p. 267, 2018. 


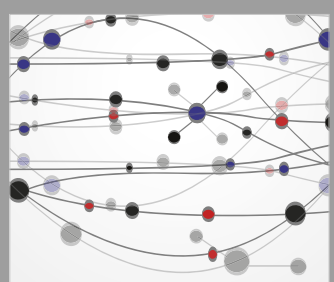

The Scientific World Journal
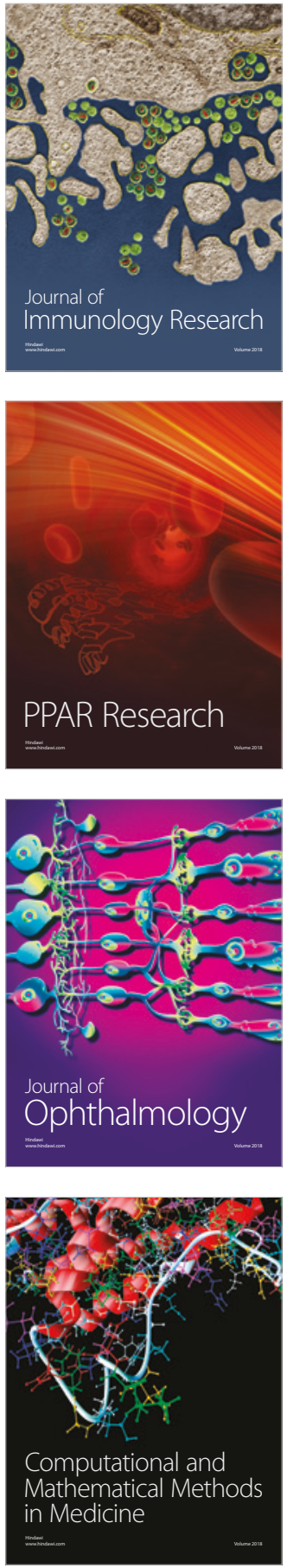

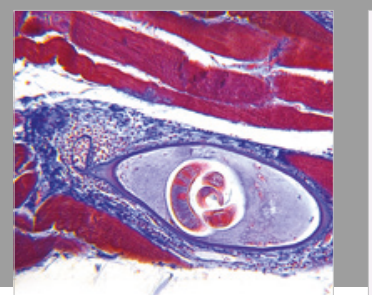

Gastroenterology Research and Practice

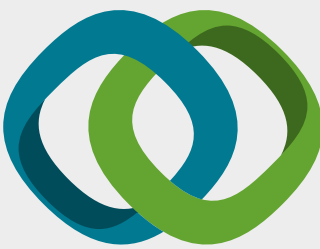

\section{Hindawi}

Submit your manuscripts at

www.hindawi.com
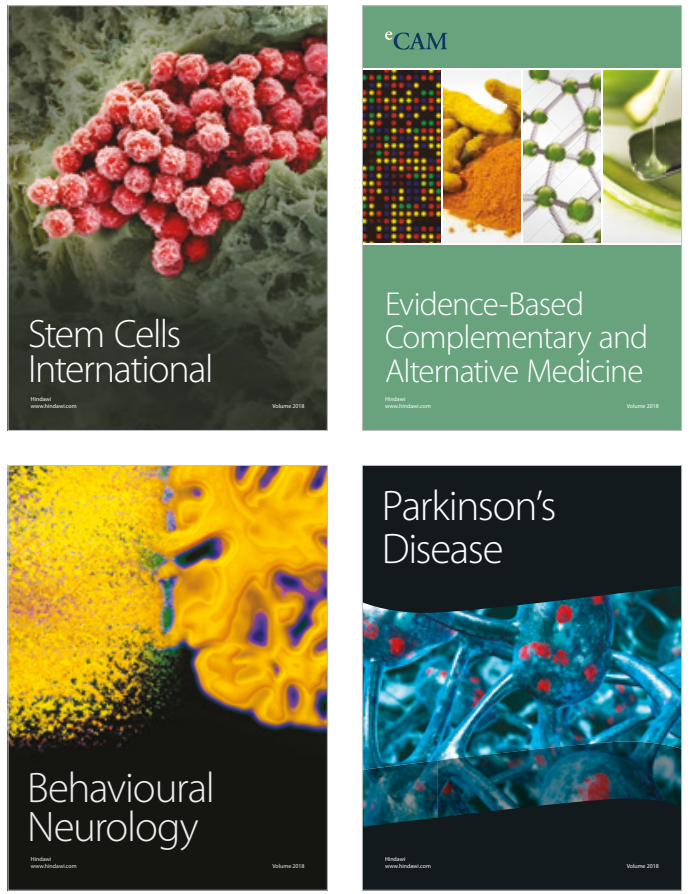

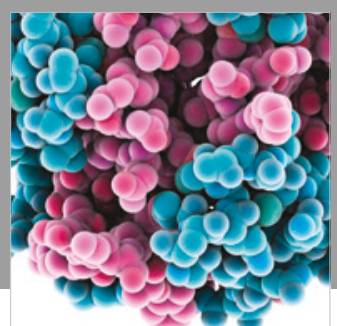

ournal of

Diabetes Research

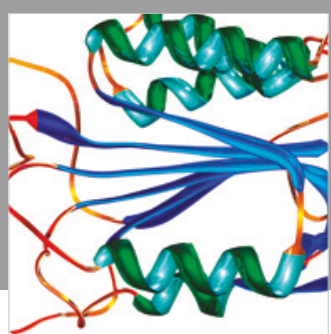

Disease Markers
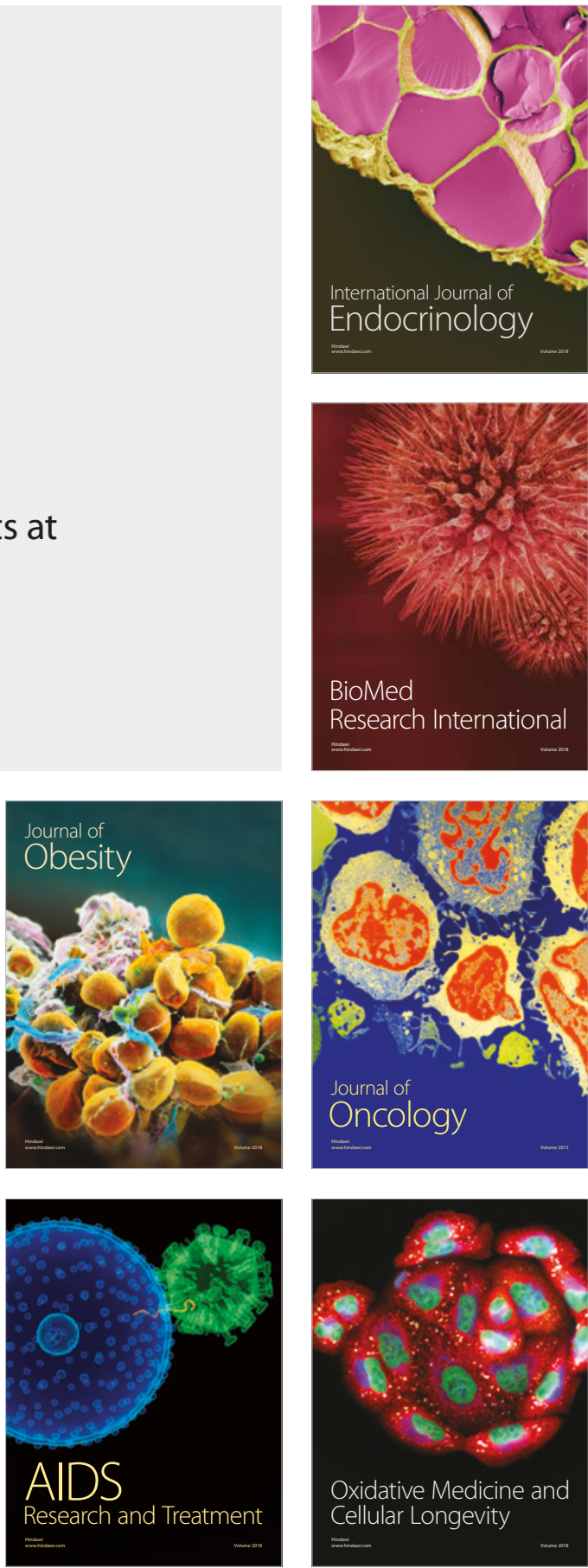